\title{
IbM BAGI PETANI BENIH UDANG WINDU SKALA RUMAH TANGGA (BACKYARD) DI DESA KALITENGAH KECAMATAN TANGGULANGIN SIDOARJO YANG MENGALAMI GAGAL PANEN BERKEPANJANGAN KARENA SERANGAN PENYAKIT
}

\section{IBM FOR SEED SHRIMP FARMERS FAMILY SCALE (BACKYARD) IN KALITENGAH VILLAGE, TANGGULANGIN DISTRICT, SIDOARJO REGION, THAT HARVESTING LOSSED TO LONG TIMES THAT CAUSED BY THE DISEASES}

\author{
Gunanti Mahasri, Sudarno dan Rahayu Kusdarwati \\ Fakultas Perikanan dan Kelautan Universitas Airlangga \\ Kampus C Mulyorejo - Surabaya, 60115 Telp. 031-5911451
}

\begin{abstract}
Demand of seed shrimp, as specially tiger shrimps is still not enough until now, it is only 50$60 \%$, more than for 5-10 years end showed decreased point. One of factors that influenced the successfully seeds shrimp hatchery is water quality that as a life media of shrimps. A bisnis about shrimp hatchery is still have a good market, because there are a lot of tiger shrimp pond operational, more than some time demand of the shrimp increase fluctuative on seasonal.

The aims of this this societies service activities is applicated a new shrimp hatcher technology by using immunostimulant at Putri Mandiri Group company, it aplicated in family hatcher in Kalitengah village, Tanggulangin District, Region of Sidoarjo. The immunostimulant use to increase the body deffence of the shrimp larve in hatchery to the disease attacked dan invirontment during culture periode, it will be increase the harvesting.

The method using in the activity were socialitation/counseling, dempond and guiding to application of the method of shrimp hatcher by using immunostimulant in one periode. Monitoring and evaluation about this result were done in one month after the activity ending.

This result showed that aplicated immunostimulant in shrimp family hatcher Backyard) can increased the shrimp seed harvesting of Putri Mandiri Company owner, from 900.000 to 1.600 .000 shrimp seeds, it is same as that the profit increased from 8.622.000,- until 15.822.000,- Rupiahs for one periode panen for one container 10 tonage capacity.
\end{abstract}

Keywords : Tiger Shrimp, Family Hatchery, Seed, Immunostimulant, Harvesting

\section{Pendahuluan}

Sebelum tahun 1994 Udang windu (Penaeus monodon Fab) merupakan primadona komoditas eksport non migas dari sektor perikanan, sehingga usaha budidaya udang ini masih mempunyai prospek yang cerah dan merupakan andalan dari sektor perikanan. Nilai eksport udang windu pada dekade sepuluh tahun yang lalu tepatnya pada tahun 1992 mencapai 1200 U\$ Dolar, dan saat itu Indonesia termasuk empat besar dunia negara pengeksport udang windu. Sebagai sumber protein udang windu juga mempunyai peran yang besar dalam pemenuhan protein hewani asal ikan, karena nilai gizinya yang tinggi (Rosati, 1994).

Tingkat keberhasilan budidaya udang windu sangat ditentukan oleh usaha pembenihan udang yang dilakukan oleh Panti Pembenihan (Hatchery), Panti Pembenihan Skala Rumah Tangga (Backyard) maupun skala besar dalam menyediakan benur udang yang berkualitas dan bebas penyakit.
Usaha pembenihan udang windu masih merupakan usaha yang terus berkembang sampai saat ini dan produksi benur yang dihasilkan baru mencapai 3.700 juta ekor per tahun dan baru dapat memenuhi kebutuhan sebanyak 40\%-50\% dari seluruh total kebutuhan (Rukyani, 1994). Akan tetapi mulai tahun 1993 produksi ini menurun sebesar $70 \%$ yang dikarenakan terjadi kasus kematian udang windu baik di tambak maupun di Hatchery, yang dikarenakan oleh serangan penyakit maupun penurunan kualitas air (Kompas, 1996).

Berbagai cara yang dilakukan untuk meningkatkan hasil panen benur tersebut sampai saat ini belum dapat diharapkan, bahkan pada saat musim tebar banyak para petambak terpaksa tidak tebar, karena tidak mendapatkan benur. Hal ini akan mengakibatkan menurunkan hasil panen yang secara otomatis akan menurunkankan penghasilan, sehingga sangat perlu dilakukan perbaikan-perbaikan teknologi 
tepat guna dalam pembenihan udang windu tersebut.

Usaha pembenihan skala rumah tangga sudah menjadi usaha alternatif bagi anggota, akan tetapi karena kasus kematian masih tetap tinggi, sehingga perlu penerapan teknologi tepat guna untuk meningkatkan hasil panennya. Kendala utama penyebab menurunnya hasil panen benur di pembenihan udang skala rumah tangga adalah adanya serangan penyakit dan penyediaan kualitas air agar kandungan oksigen dalam bak pembenihan dapat optimal. Untuk mengatasi kendala tersebut perlu dilakukan suatu upaya agar larva udang yang dipelihara di panti pembenihan tahan terhadap lingkungan yang kurang sesuai dan tahan terhadap serangan penyakit. Salah satu upaya yang diterapkan pada kegiatan ini adalah penggunaan imunostimulan (imunisasi) terhadap larva udang (Stadia Zoea) yang akan dipelihara untuk dijadikan benih. Mahasri (2007) mengatakan bahwa penggunaan imunostimulan dari protein membran parasit dapat menurunkan infestasi protozoa patogen dan meningkatkan tingkat kelangsungan hidup udang stadia juvenil dari $10 \%$ hingga $70 \%$. Imunostimulan ini akan merangsang dan meningkatkan aktivitas sel-sel pertahanan tubuh sehingga dapat tahan terhadap serang penyakit. Bertitik tolak dari uraian di atas maka tujuan dari program pengabdian kepada masyarakat ini adalah menerapkan metode pembenihan udang dengan menggunakan imunostimulan di panti pembenihan skala rumah tangga milik Putri Mandiri Grup untuk meningkatkan hasil panen benih udang.

\section{Materi dan Metode}

Berdasarkan identifikasi permasalahan pada mitra, maka permasalahan utama yang harus segera ditangani adalah : 1) Menurunnya hasil panen yang drastis yang terjadi sejak tahun 1999, 2) Permasalahan banyaknya tempat pembenihan udang skala rumah tangga yang tidak produktif, rusak dan tidakkan dapat diguna operasional (Idle), 3) Banyaknya Petani benih udang di Desa Kali Tengah yang gulung tikar, 4) Penghasilan petani benih udang yang sangat rendah (< Rp. 2.000.000,-), 5) Rendahnya pengetahuan dan keterampilan dalam melaksanakan usaha pembenihan udang dan 6) Meningkatnya pengangguran karena dengan tidak operasionalnya usaha p[embenihan menjdikan banyak petani yang kehilangan pekerjaan, terutama usia dewasa dan remaja.

$$
\text { Metode pelaksanaan kegiatan }
$$

pengabdian masyarakat dengan penerapan atau penggunaan imunostimulan ini terdiri dari tiga tahap yaitu : (a) tahap penataan dan perbaikan bak pembenihan, (b) tahap penyuluhan dan peragaan dari teknologi yang diterapkan dan (c) tahap penggunaan imunostimulan di tempat pembenihan udang skala rumah tangga, dengan membuat percontohan satu kali periode panen.

Tahap Penataan dan Perbaikan Bak Pembenihan

Tahap ini akan dilakukan langsung di tempat pembenihan milik salah satu petani benih udang di lokasi yang bergabung manajemen CV. Putri Mandiri Grup. Proses pembuatannya meliputi : (1) Penyedian bak pembenihan, (2) Penyiapan dan pembuatan imunostimulan, dan 3) Penyediaan satu set bak pembenihan udang yang sudah dilakukan untuk uji coba.

Tahap penyuluhan dan peragaan

Tujuan dari tahap ini adalah untuk meningkatkan pengetahuan dan keterampilan para petani benih udang khususnya tentang teknologi pembenihan udang dengan menggunakan imunostimulan. Penyuluhan dan peragaan cara penggunaan imunostimulan pada Zoea udang yang dilakukan di salah satu tempat pembeinhan milik petani yang bergabung pada manajemen CV. Putri Mandiri Grup. Pemilihan lokasi ini dengan pertimbangan efektivitas dan efisiensi kerja tim pelaksana pengabdian kepada masyarakat dan kemudahan pihak khalayak sasaran untuk menghadirinya. Metoda yang digunakan dalam tahap ini adalah tutorial dan visualisasi, kemudian dilanjutkan dengan diskusi materi penyuluhan. Adapun materi penyuluhan meliputi tentang teknologi pembenihan udang dengan penggunaan imunostimulan. Tahap peragaan penggunaan imunostimulan secara langsung dilakukan di lokasi tempat pembenihan sehingga khalayak sasaran dapat lebih memahami dan mengerti materi penyuluhan dengan baik sehingga dapat mengoperasikannya di lapangan.

Tahap Penerapan dan Pendampingan Pembenihan Udang Dengan Imunostimulan.

Tahap ini merupakan tahap penerapan langsung pembenihan udang windu dengan menggunakan imunostimulan pada pembenihan udang. Tahap ini diawali dengan pengecekan ulang kesiapan, renovasi bak pembenihan. Penyediaan benih dilakukan oleh tim penyuluh , dalam hal ini tim penyuluh bersifat sebagai pembimbing selama satu siklus pembenihan udang yaitu kurang lebih selama 2-3 bulan. Selama masa pemeliharaan udang satu siklus, kegiatan yang dilakukan adalah melakukan 
pengontrolan kondisi kesehatan udang dan kualitas air serta pertumbuhan benih udang sebagai data pendukung penilaian tingkat keberhasilan penggunaan imunostimulan yang diterapkan. Dalam melaksanakan pembenihan udang ini dilakukan pendampingan oleh Tim pengmas selama satu periode panen yaitu selama 3 bulan. Tujuan pendampingan ini adalah untuk membimbing dan mengajari secara langsung cara pelaksanaan pembenihan udang dengan penggunaan imunostimulan.

\section{Partisipasi Mitra Dalam Pelaksanaan Program}

Untuk memperlancar kegiatan ini partisipasi dari mitra sangat diharapkan, karena keberhasilan dari program ini terletak di tangan mitra. Mitra sebagai sasaran program akan berpatisipasi pada tiap-tiap tahap atau langkah pelaksanaan. Partisipasi ini berupa peserta dalam penyuluhan dan peragaan dan sebagai pelaksana dalam penerapan teknologi imunisasi ini di lokasi dengan pendampingan oleh Tim Pengmas dalam satu periode panen. Partisipasi yang dilakukan oleh Kelompok petani di Desa Kalitengah adalah mendukung sebagian dana dan tempat (penyediaan tambak) untuk pelaksanaan program ini dan turut langsung pelaksanaannya didampingi oleh Tim Pengmas.

Peran mahasiswa dalam kegiatan ini adalah membantu dalam pelaksanaan persiapan, penyuluhan, peragaan dan pendampingan. Selama pendampingan mahasiswa akan bertugas mencatat jalannya pelaksanaan dan membimbing mitra (petani) dalam mengukur parameter kualitas air. Mahasiswa ditugaskan secara bergantian sehingga tidak mengganggu aktivitas perkuliahan.

\section{Hasil dan Pembahasan}

Sosialisasi merupakan suatu kegiatan penyebar luasan informasi tentang metode pembenihan udang dengan menggunakan imunostimulan, kemudian dilakukan penyuluhan dan diakhiri dengan demonstrasi / peragaan cara imunisasi pada udang stadia zoea sebelum ditebar dalam bak pembenihan.

Imunostimulan yang digunakan dalam kegiatan pengabdian kepada masyarakat ini adalah imunostimulan dari protein membran imunogenik dari Zoothamnium penaei yang juga sudah berhasil digunakan dalam pembesaran udang di tambak terutama di lokasi pertambakan di Jawa Timur. Dalam kegiatan ini imunostimulan tersebut digunakan untuk mengimunisasi larva udang (Satdia Zoea) sebelum dipelihara menjadi benih (PL-12). Imunostimulan ini akan berfungsi untuk meningkatkan aktivitas sel pertahanan tubuh udang sehingga akan meningkat pula ketahanan tubuh udang dalam menahan serangan penyakit. Mahasri (2012) sudah berhasil meningkatkan produksi udang vannamei dari $25 \%$ hingga $86 \%$.

Usaha budidaya udang windu masih mempunyai prospek yang carah, karena tingkat keberhasilannya sangat tergantung pada keberhasilan hatchery (tempat pembenihan) baik skala besar maupun backyard dalam menghasilkan bernur yang berkualitas dan bebas penyakit. Kebutuhan benur udang windu maupun udang jenis lain, sampai saat ini baru dapat terpenuhi sekitar 50-60\% (DKP, 2005), dengan rincian benur yang berasal dari alam hanya mencapai $20 \%$ dan dari hatchery mencapai $40-50 \%$.

Pembenihan udang skala rumah tangga (Banckyard) merupakan suatu usaha pembenihan udang windu dalam skala kecil dengan memanfaatkan halaman rumah atau lahan kosong sebagai lokasi usaha. Backyard ini umumnya dilaksanakan oleh sebuah keluaga dengan anggota keluarga sebagai tenaga pelaksana (Sutaman, 1993). Teknologi yang digunakan dalam operasional sangat sederhana dengan modal yang kecil dan kegiatannya hanya sebagian dari rangkaian pembenihan udang di hatchery (Heryadi dan Sutadi, 1993). Walaupun skala kecil, tingkat keuntungan dari bakyard ini dapat mendatangkan keuntungan yang besar, apabila dikelola dengan profesional. Umumnya para pengusaha besar juga dapat memanfaatkan teknologi backyard dalam sebuah mini hatchery.

Kegiatan pada backyard adalah memelihara benur dari stadia Nauplius (stadia stelah telur menetas) sampai pada stadia PL-11 ( Pasca Larva 11), yang siap ditebar di tambak (Martosudarmo dan Ranoemihardjo, 1998). Kegiatan dimulai dengan persiapan semua alat dan bahan yang dibutuhkan selama kurang lebih 2 minggu. Stadia Nauplius yang yang ditebar memerlukan waktu tumbuh sekitar $4-5$ hari. Stadia berikutnya adalah Mysis yang dialami selama 3- 4 hari, baru kemudian berubah menjdi stadia pasca larva yang membutuhkan waktu selama 11 hari. Pada saat pasca larva umur 11 hari ini benur siap tebar di tambak. Dengan demikian waktu keseluruhan yang diperlukan untuk satu periode panan adalah kurang lebih 30 hari, stadia nauplius dapat diperoleh dari hatchery besar di sentral pembenihan udang (Sutarman, 1993).

(Rukyani,1993) menyatakan bahwa faktor penyebab kegagalan dalam usaha backyard ini antara lain : teknik pemeliharaan yang kurang diperhatikan, pengelolaan kualitas air yang kuarang baik, kulaitas dan kuantitas 
pakan serta penyakit. Air merupakan media hidup bagi udang, sehingga pengelolaan kualitas air sangat perlu untuk diperhatikan dalam usaha pembenihan udang. Air yang digunakan dalam pembenihan udang sekala rumah tangga umumnya diperoleh dengan membeli dari suatu perusahaan air laut untuk mini hatchery dan hatchery besar biasanya sudah mempunyai tandon, pompa dan seperangkat filter untuk memperoleh air yang berkualitas.

Hasil pemeriksaan parameter kualitas air pada bak pembenihan menunjukkan bahwa air selalu dalam kondisi optimal untuk pembenihan udang windu. Adapun hasil pemeriksaan kualitas air selama pemeliharaan benur udang disajikan pada tabel 1 .

Demonstrasi ini ditujukan untuk meningkatkan keterampilan petani tentang teknik operasional pembenihan udang sekala rumah tangga dengan menggunakan imunostimulan. Kegatan ini dilaksanakan langsung di tiap-tiap lokasi di pembenihan udang sekala rumah tanggga milik CV. Putri Mandiri Group (door to door)., Pelaksanaan kegiatan ini meliputi : peragaan / demonstrasi cara imunisasi, pergaan cara pembuatan atau persiapan bak pembenihan di bak-bak pembenihan dan demonstrasi mengenalkan benih yang berkualitas

Tujuan Dari pembimbingan atau pendampingan ini adalah untuk membimbing secara langsung pembenihan udang mulai dari persiapan sampai dengan panen benur dengan menggunakan imunostimulan selama 1 periode pemeliharaan. Bak yang digunakan dalam pembenihan ini terdiri dari 2 buah bak yang berbentuk persegi empat dan berkapasitas 10 ton.

Persiapan pembenihan dimulai dengamn pembersihan bak-bak dengan menggunakan formalin dan klorin 10 ppm. Kemudian dilakukan pengeringan dan diteruskan dengan pengolahan (treatment) air untuk pemeliharaan. Bahan kimia yang digunakan untuk mengolah air terdiri dari saringan air (filter back), natrium thiosulfat dan EDTA. Setelah selesai air diendapkan selama 2 hari dan kemudian diisikan pada bak-bak yangakan digunakan untuk pemeliharaan.
Nauplius yang ditebar dibeli dari tempat pembenihan udang di desa Kembang sambi, Situbondo, dan dibawa dengan menggunakan kantong plastik yang diberi oksigen. Setelah diaklimatisasi langsung ditebar ke dalam bakbak pemeliharaan, zoea yang ditebar sebanyak 2.000.000 ekor. Sebelum ditebar semua larva stadia zoea dilakukan imunisasi terlebih dahulu, uuntuk meningkatkan aktivitas sel-sel pertahanan tubuh, sehingga tahan terhadap penyakit maupun lingkunagn perairan. Pemberian pakan dilakukan setelah stadia Zoea, dimana pakannya terdiri dari pakan buatan dan pakan alami. Cara penyediaan pakan dan pemberian sudah diuraikan pada tahap penyuluhan.

Tingkat keberhasilan usaha backyard udang, berdasarkan keadaan di lapangan adalah lebih dari $60 \%$ berhasil, ini berarti peluang keberhasilannya lebih besar dari pada peluang kegagalannya (Heryadi dan Sutadi, 1993). Selanjutnya dikatakan bahwa umumnya titik impas usaha (BEP) diperoleh bila kehidupan larva (benur) selama pemeliharaan minimal 10 $\%$ dari jumlah Zoea yang ditebar. Padahal dalam prakteknya, apabila di tangani dengan baik, tingkat kehidupan larva bisa mencapai 70 $\%$ - $80 \%$. Akan tetapi rata-rata di lapangan menunjukkan bahwa umumnya mencapai $25 \%$. Ini berarti tingkat keuntungan bisa mencapai tiga sampai empat kali biaya operasional. Dengan lain perkataan bahwa " apabila satu kali berhasil, maka kegagalan sampai tiga kali pun belum dikatakan rugi. Waktu pemeliharaan hanya sekitar 23- 25 hari, gejala kegagalan pun seandainya akan terjadi sudah dapat diketahui secara dini, paling lambat 15 hari setelah penebaran, ini berarti akibat kegagalan dapat di tekan lebih kecil lagi.

Tingkat keberhasilan usaha ini adalah lebih dari $75 \%$ berhasil, ini berarti peluang keberhasilannya lebih besar dari pada peluang kegagalannya. Titik impas (BEP) di peroleh bila kelulushidupan larva (benur) selama pemeliharaan minimal $10 \%$ dari jumlah Nauplius yang ditebar. Padahal dalam prakteknya, apabila ditangani dengan baik, tingkat kehidupan larva dapat mencapai 80-90 $\%$. Akan tetapi rata-rata di lapangan

Tabel 1. Hasil Pemeriksaan Kualitas Air Bak Pembenihan Selama Pemeliharaan benih udang

\begin{tabular}{|c|l|c|c|}
\hline No & \multicolumn{1}{|c|}{ Parameter } & Hasil Pemeriksaan & Kisaran Toleransi \\
\hline 1. & Oksigen Terlarut $(\mathrm{ppm})$ & $5-6$ & $4-8$ \\
2. & Suhu $\left({ }^{0} \mathrm{C}\right)$ & $28-29$ & $27-32$ \\
3. & Salinitas $(\mathrm{ppt})$ & $22-24$ & $20-30$ \\
4. & $\mathrm{pH}$ & $8,2-8,5$ & $7,7-9$ \\
5. & Nitrit $(\mathrm{ppm})$ & $0,02-0,03$ & $<0,1$ \\
\hline
\end{tabular}


menunjukkan bahwa pada umumnya hanya mencapai $25 \%$. Pada kegiatan ini padat tebar zoea adalah 2.000.000 ekor per 10 ton. Hasil panen benih pada satu periode pemeliharaan tanpa menggunakan imunostimulan pada kegiatan ini adalah 900.000 ekor, berarti tingkat kelulushidupan benih (SR) sebesar $45 \%$, sedang dengan menggunakan imunostimulan hasil panen benih 1.600 .000 ekor, berarti tingkat kelulushidupannya (SR) mencapai $80 \%$.

Faktor-faktor penyebab kegagalan dalam usaha ini antara lain adalah : teknik pemeliharaan yang kurang diperhatikan, pengelolaan kualitas air kurang baik, kualitas dan kuantitas pakan serta penyakit. Dari keempat faktor utama tersebut yang sangat penting untuk diperhatikan adalah faktor penyakit, sebab datangnya secara mendadak dan dapat menimbulkan kematian total dalam waktu 2 hari setelah infeksi, bahkan penyakit tertentu hanya beberapa jam setelah infeksi.

Hasil analisis menunjukkan bahwa keuntungan bersih per siklus pembenihan tidak menggunakan imunostimulan adalah Rp. 8.622.000,- sedangkan dengan menggunakan imunostimulan, keuntungan bersih persiklus mencapai Rp. 15.822.000,- hal ini dapat diartikan bahwa dengan imunostimulan mendapatkan keuntungan sebesar Rp. 7.200.000,- / bak 10 ton.

Hambatan yang dijumpai dalam kegiatan ini adalah agak sulitnya mentransfer ilmu pengetahuan tentang penggunaan imunostimulan dalam pembenihan udang. Hal ini dikarenakan kebenyakan para teknisi di CV. Putri Mandiri Grup mempunyai tingkat pendidikan yang rendah. Disamping itu mereka hanya bisa mengoperasionalkan pembenihan, tidak diberi pengertian apabila ada masalah bagaimana cara penanggulangannya. Untuk mengatasi hambatan tersebut maka dilakukan pendampingan / pembimbingan langsung, sehingga kalau ada masalah muncul disaat operasional, Langsung dilakukan penanganan dan diberi tahu cara penyelasaiannya. Faktor pendukung dari kegiatan ini adalah adanya semangat dari para teknisi untuk meningkatkan hasil / produksi. Disamping iu juga adanya fasilitas yang memadai siapnya perusahaan menerima program kegiatan ini.

Tingkat keberhasilan dari kegiatan ini dapat dilihat dari adanya peningkatan hasil produksi benur. Apabila dilihat dari analisis usaha, maka dengan adanya penerapan imunostimulan pada pembenihan udang skala rumah tangga CV. Putri Mandiri Grup, terdapat peningkatan produksi benur dari 900.000 ekor ( SR) menjadi 1.600 .000 ekor dalam satu siklusnya. Sedangkan apabila diihat keuntungannya, maka dengan imunostimulan, keuntungan yang diperoleh adalah 15.822.000,(Lima Belas Juta Delapan Ratus Dua Puluh Dua Ribu Rupiah), lebih besar jika dibandingkan dengan tanpa menggunakan imunostimulan, yaitu 8.622.000,- (Delapan Juta Enam Ratus Dua Puluh Dua Ribu Rupiah).

\section{Kesimpulan}

Kesimpulan yang dapat diajukan dari hasil kegiatan pengabdian kepada masyarakat ini adalah : Imunostimulan yang digunakan pada pembenihan udang skala rumah tangga yang diterapkan pada stadia zoea dapat meningkatkan ketahanan tubuh udang dan memberikan perlindungan selama masa pemeliharan benih. Penerapan imunostimulan pada pembenihan udang skala rumah tangga milik CV. Putri Mandiri Grup dapat meningkatkan hasil panen benur udang dari 900.000 ekor menjadi 1.600 .000 ekor dengam nilai rupiah keuntungan meningkat dari Rp. 8.622.000,- menjadi 15.822.000,-, sehingga dengan imunostimulan perperiode panen per bak dengan kapasitas 10 ton mendapatkan keuntungan sebesar Rp. 7.200.000,-. Saran yang diajukan setelah selesainya kegiatan pengabdian kepada masyarakat ini adalah : Untuk menerapkan model pembenihan udang dengan imunostimulan disarankan minimum menggunakan 5 bak untuk mendapatkan keuntungan yang maksimal. Selama pemeliharaan benih harus dilakukan pemantauan kualitas air untuk mendukung pertumbuhan benih udang.

\section{Daftar Pustaka}

Aji, B., S. Ginting dan M. Cristina. 1998. Rezeki dari Si Bongkok. Kontan. No. 40.Tahun II.

Asian Shrimp News, 2005, Availability of Natural Black Tiger Shrimp Broodstock and Seed Supply, Asian Shrimp Culture Counsil Published, Q 4 / Issue No. 20

Chifumi, Thongchai, Osamu \& Kurokura, 2005. Incentive to shifts in Water management systems by shrimp culturist in Shouthern Thailand, Fisheries Science, Vol 71, Issue 4, Pages 791-8

German, M, Eduardo U, Gasper S \& Elizabeth V.B, 2008. A Comparison of Larval production of the Nothern scallop, Argopertempurpuratus, in closed and recirculating Culture system, J.Aquaeng, Vol 38, 11.004. 
Haryanti. 2004. Broodstock Udang Vannamei. Makalah pada Seminar Sehari Perudangan Nasional: Upaya Mengatasi Problem Teknis dan Pemasaran Udang Melalui Standarisasi Budidaya.

Hidayat, T, 1992, Pengelolaan Kualitas air sebagai Upaya Pencegahan timbulnya Penyakit, Makalah Pertemuan Teknik Budidaya Air Payau, Bangil Jawa Timur, 15 November 1992, Hal. 1 - 12.

Liao, I. C. 2000. Aquaculture Development: Challenges for the $21^{\text {st }}$ Century.

Maeda, M, K.Nogami \& Y. Kotami, 200. Manipualtion of microbiol communities for Improving the Aquaculture Environment, J. Aquaculture, $02.035: 192-8$

Mahasri,G, 2007. Kemampuan ikan Bandeng sebagai Filter Biologi dalam Menekan Pertumbuhan Ciliata Patogen pada Tambak, LPPM Universitas Airlangga, Surabaya

Moss, S. M. and S. M. Arce. 2003. SPF Defined: Pathogen - Free Status of Shrimp Limited. Global Aquaculture Advocate.

Rosati, R, 1994, Indonesian Shrimp Industry Status and Development Project, Puslitbang Perikanan, Jakarta

Rosy, L.J, Valeriano, L.C.Jr \& Taizos, 2004. Water quality and plytoplankton Stability in Response to application frequency of Bioargumentation agent in Shrimp pond. In Press, Accepted Manuscript, Available on line Aquaculture Enginering doi 10.10.J.Aqua Eng.01.001 page :200-5

Rukyani, A, 1994, Jenis Penyakit Udang, Makalah Pertemuan Aplikasi Paket Teknologi Pertanian, BIP Lampung, 9 - 11 Januari 1994.
Sharift, M, F.M Yosoff, T.N Devaraja \& Srinivasan R, 2001. The Effectiveness of a commercial microbiol product in Poorly prepared tiger shrimp Penaeus monodon ponds, Aquaculture Research Vol 32 Issue $3:$ : 181-7

Subandriyo, 2001, Budidaya Udang dengan Sistem Resirkulasi dan Masalahnya, Pt. Charoen Pokphand Indonesia, Medan.

Supito, A. Taslihan dan M. Murdjani. 2004. Solusi Pencegahan White Spot pada Pembesaran

Udang Windu di Tambak Sidoarjo dan Gresik Dengan Penerapan BMP Balai Besar Pengembangan Budidaya Air Payau

Syarief, H dan Faisol Humaidi, 2006, Budidaya Udang Air Payau Sistem Tradisi Berbasis Organik di Sidoarjo, Makalah Pertemuan Penerapan Teknologi BMP untuk Mendukung Revitalisasi Budidaya Udang, DKP - ACIAR, Surabaya 6 - 8 Maret 2006. Hal 1 - 20.

Taslihan, A, Supito, Erik Sutikno, R.B. Callinan, 2005, Teknik Budidaya Udang Secara Benar, Balai Besar Pengembangan Budidaya Air Payau, Ditjen Perikanan Budidaya, Jakarta. Warta Pasar Ikan. 2005. Warta Pasar Ikan. Direktorat Jenderal Perikanan. Departemen Kelautan dan Perikanan. Jakarta.

Wu Xiongfei \& Z. Zhidong, 2005. Closed recirculating system for shrimpmoluscha polyculture, J.oceano-limno, Vol 24 No 4 : 461-8

Yoram, A, 2006. Biofilters : The need for a new Comprehensive Approach, J.Aquaeng, Vol $34: 172-8$ 